\title{
REVISED STREAM CODE BENCHMARKING WITH 1991 K-REACTOR TRITIATED AQUEOUS RELEASE INCIDENT (U)
}

Kuo-Fu Chen

Technical Reviewer

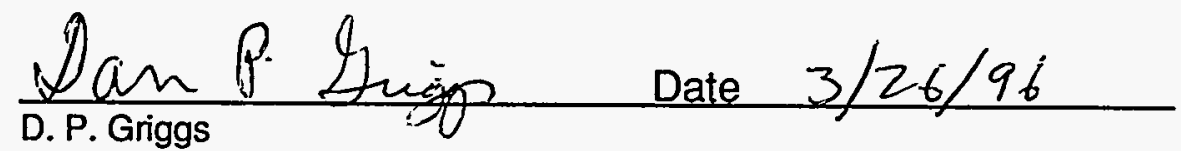

Approval

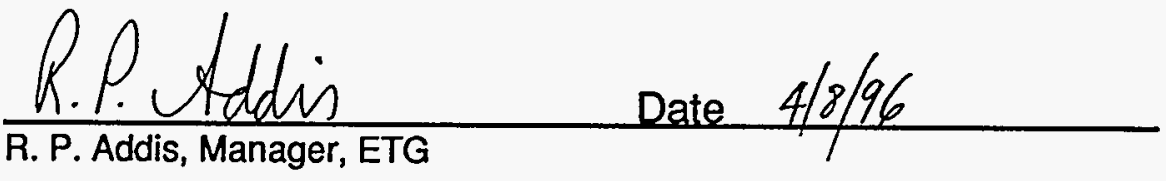

Q1 Lamittor a L Bomi Date $4 / 23 / 26$

A. L. Boni, Mahager, ETS

March 1996"

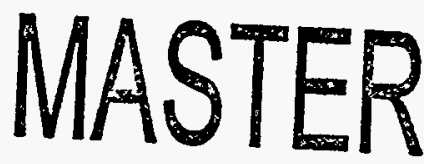

Westinghouse Savannah River Company Savannah River Site Alken, SC 29808

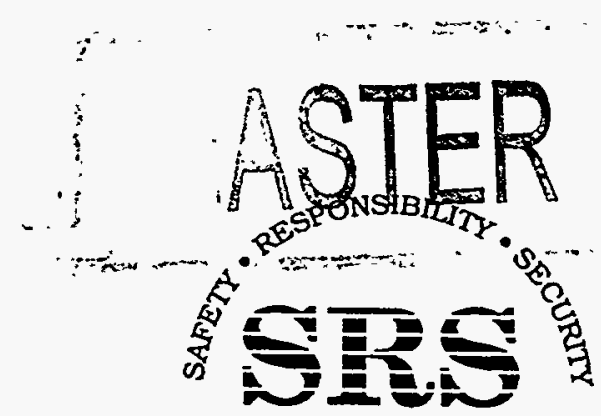

SAVANNAH RIVER SITE

PREPARED FOR THE U.S. DEPARTMENT OF ENERGY UNDER CONTRACT NO. DE-ACO9-89SR18035 IETRIBUTION OF THIS DOCUMENT IS UMLIMTO 


\section{DISCLAIMER}

Portions of this document may be illegible in electronic image products. Images are produced from the best available original document. 


\section{DISCLAIMER}

This report was prepared as an account of work sponsored by an agency of the United States Government. Neither the United States Government nor any agency thereof, nor any of their employees, makes any warranty, express or implied, or assumes any legal liability or responsibility for the accuracy, completeness, or usefulness of any information, apparatus, product, or process disclosed, or represents that its use would not infringe privately owned rights. Reference herein to any specific commercial product, process, or service by trade name, trademark, manufacturer, or otherwise does not necessarily constitute or imply endorsement, recommendation, or fakoring by the United States Government or any agency thereof. The views and opinions of authors expressed herein do not necessarily state or reflect those of the United States Government or any agency thereof. 


\title{
REVISED STREAM CODE BENCHMARKING WITH 1991 K-REACTOR TRITIATED AQUEOUS RELEASE INCIDENT (U)
}

\author{
Kuo-Fu Chen
}

Issued: March 1996

SRTC SAVANNAH RIVER TECHNOLOGY CENTER AIKEN, SC 29808 Westinghouse Savannah River Company Savannah River Site Aiken, SC 29808 


\section{ABSTRACT}

The transport and diffusion module of the WIND System aqueous emergency response program (STREAM code) was replaced with the EPA WASP5 code. A set of input data was developed to model the transport of pollutants from a release point in K-Area to Savannah, Georgia through Indian Grave Branch, Pen Branch, the SRS swamp, Steel Creek, and the Savannah River.

To evaluate the modifications to the STREAM code, data from an accidental release of tritiated water from K-Reactor in 1991 were used for benchmarking. A leak in a heat exchanger allowed a small amount of reactor coolant water to be released to cooling streams onsite, eventually reaching the Savannah River. Measurements of tritium concentration were taken at several downstream locations during the release. The results show that the revised STREAM code overpredicts the peak concentrations by 3 to $15 \%$, which is comparable to the measurement uncertainty (one standard deviation). The revised STREAM code underpredicts the transport times of the concentration peak by 18 to $37 \%$. The discrepancies in the travel time could result from uncertainties in the start of the release. The revised STREAM code performed well in simulating both the timing and the magnitude of the maximum observed tritium concentration. This gives confidence that the code can perform well both for emergency response and other engineering or safety analyses. 


\section{TABLE OF CONTENTS}

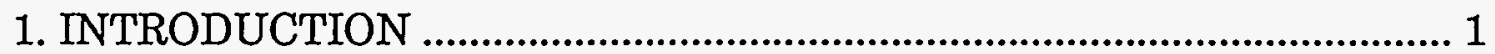

2. $1991 \mathrm{~K}$-REACTOR TRITIATED WATER RELEASE INCIDENT ............ 1

3. MODEL DESCRIPTION .................................................................... 2

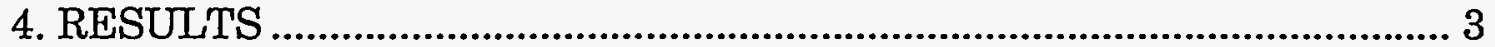

5. CONCLUSIONS ....................................................................................... 3

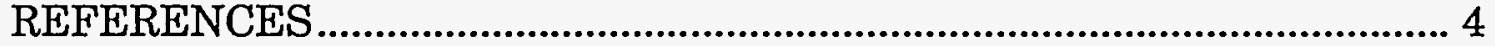

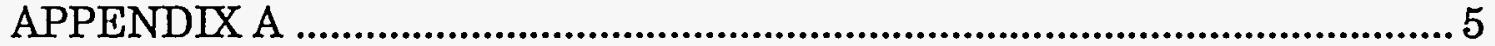




\section{LIST OF TABLES}

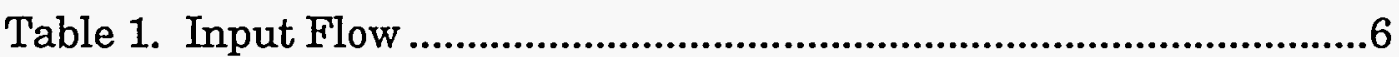

Table 2. Model Comparison Summary …..............................................

\section{LIST OF FIGURES}

Figure 1. Path followed by tritium from K Area to the Savannah River estuary after December 1991 release 8

Figure 2. Model Schematics (Not to Scale) ............................................9

Figure 3. Measured Savannah River Stage at Steel Creek Mouth

Figure 4. Model Simulation for $1991 \mathrm{~K}$-Reactor Tritiated Water Release Incident (Tritium Concentration at Steel

Creek)

Figure 5. Model Simulation for 1991 K-Reactor Tritiated Water Release Incident (Tritium Concentration àt Highway 301)

Figure 6. Model Simulation for $1991 \mathrm{~K}$-Reactor Tritiated Water Release Incident (Tritium Concentration at Becks Ferry)

Figure 7. Model Simulation for 1991 K-Reactor Tritiated Water Release Incident (Tritium Concentration at Abercorn Creek) 


\title{
REVISED STREAM CODE BENCHMARKING WITH $1991 \mathrm{~K}$ - REACTOR TRITIATED AQUEOUS RELEASE INCIDENT (U)
}

\author{
By Kuo-Fu Chen \\ Westinghouse Savannah River Company \\ Savannah River Site \\ Aiken, SC 29808
}

\section{INTRODUCTION}

STREAM is an aqueous emergency response code of the Weather Information and Display (WIND) System. STREAM predicts downstream pollutant concentrations for releases from the SRS area to the Savannah River. The transport and diffusion module of the STREAM code was replaced with the WASP5 code [1]. WASP5 [2] is a US EPA water quality analysis program that simulates one-dimensional pollutant transport through surface water. WASP5 uses a finite difference method to solve the advective transport equation.

A set of input data was developed to model the transport of pollutants from a release point in K-Area to Savannah, Georgia through Indian Grave Branch, Pen Branch, the SRS swamp, Steel Creek, and the Savannah River. To evaluate the modifications to the STREAM code, data from an accidental release of tritiated water from K-Reactor in 1991 were used for benchmarking. A leak in a heat exchanger allowed a small amount of reactor coolant water to be released to cooling streams onsite, eventually reaching the Savannah River. Measurements of tritium concentration were taken at several downstream locations during the release. The results show that the revised STREAM code overpredicts the peak concentrations by 3 to $15 \%$, which is comparable to the measurement uncertainty (one standard deviation). The revised STREAM code underpredicts the transport times of the concentration peak by 18 to $37 \%$. The discrepancies in the travel time could result from uncertainties in the start the release. The revised STREAM code performed well in simulating both the timing and the magnitude of the maximum observed tritium concentration. This gives confidence that the code can perform well both for emergency response and other engineering or safety analyses.

\section{1991 K-REACTOR TRITIATED WATER RELEASE INCIDENT [3]}

At the end of 1991, there was an unplanned release of tritium from KReactor. The tritium (in the form of tritiated heavy water) was released between December 22 and December 25, 1991, through the K-Reactor secondary cooling water discharge. Samples of reactor discharge water taken twice per day showed no evidence of leakage until the morning of December 
22. A sample of discharge water collected on the evening of December 22, however, indicated elevated concentration of tritium upon later analysis. Analyses of samples collected the following day were inconsistent and the elevated concentrations were not confirmed until December 24 . The leak was positively identified and isolated on December 25. Released tritium was tracked and measured as it traveled from Indian Grave Branch into Pen Branch, through the Savannah River swamp, past the mouth of Steel Creek, and down the Savannah River. The measured tritium concentrations at Steel Creek, Highway 301, Becks Ferry and Abercorn Creek were used for benchmarking. The tritium released during this event was estimated to be 5,700 Curies.

\section{MODEL DESCRIPTION}

\section{Stream and River Geometry}

The K-Area outfalls discharge to Indian Grave Branch, which flows into Pen Branch about five (5) miles upstream from the swamp. Pen Branch enters the swamp about three (3) miles from the Savannah River, flows directly toward the Savannah River for about 1.5 miles, and then turns and runs parallel to the Savannah River for about five (5) miles before discharging into Steel Creek about 0.5 mile from where Steel Creek empties into the Savannah River, as shown in Figure 1.

The river system modeled includes Indian Grave Branch;-part of Pen Branch, part of Steel Creek, and the Savannah River, as shown in Figure 1. The reach from Point 1 to Point 2 (Figure 1) was divided into 38 segments, each with a segment length of $500 \mathrm{~m}$ (0.31 mile) and a cross section area of 11.33 $\mathrm{m}^{2}\left(122 \mathrm{ft}^{2}\right)$. The reach from Point 2 to Point 3 is in the swamp area and was divided into 22 segments, each with a segment length of $500 \mathrm{~m}$ (0.31 mile) and a cross section area of $197.14 \mathrm{~m}^{2}\left(2122 \mathrm{ft}^{2}\right)$. The Savannah River from the point of $30.5 \mathrm{~km}$ (19 river miles) downstream from the New Savannah Bluff Lock and Dam to the point of $14.5 \mathrm{~km}$ (9 river miles) upstream from Fort Pulaski was divided into 489 segments, each with a segment length of $500 \mathrm{~m}(0.31 \mathrm{mile})$ and a cross section area of $278 \mathrm{~m}^{2}\left(2454 \mathrm{ft}^{2}\right)$. The cross section areas of the reaches were estimated from the Manning Equation (shown in Appendix A).

Another model input is segment volume. WASP5 uses segment volume to calculate the transport time by dividing the segment volume by the volumetric flow rate. The segment volumes are derived by multiplying the segment cross-sectional area with the segment length, except Segment 114 that represents the mouth of Steel Creek. Figure 3 shows the Savannah River stage at the Steel Creek mouth. The river stage at Steel Creek was rising from December 23 to December 31, 1991. This rising river stage would slow down the tritium transport from Steel Creek to the Savannah River. To catch these hydrodynamic effects with the current WASP5 model, the volume of Segment 114 was adjusted such that the predicted tritium concentration 
profile at Highway 301 agreed with the measurement. The adjusted volume of Segment 114 was 2,278,125 cubic meters. This implies that to further improve the WASP5 model to handle rapidly changing flow conditions, a hydrodynamic model is required.

\section{Boundary Conditions}

Figure 2 shows the schematic of the finite difference model. The required boundary conditions are the Savannah River flow at Segment 1, the Pen Branch flow at Segment 54, and the Steel Creek flow at Segment 551. Daily averaged flows (Table 1) from December 22, 1991, to January 22, 1992, for the Savannah River, Pen Branch and Steel Creek were obtained from the U.S. Geological Survey Water Resources Data in South Carolina [4].

\section{Source Term}

Reference 3 estimated that 5,700 Curies of tritium were released between December 22 and 25, 1991. The model assumed that the release started at 12:00 noon on December 22, 1991 and was isolated at 12:00 noon on December 25, 1991 with a release rate of 1,900 Curies per day. This corresponds to a total release of 5,700 Curies of tritium in three days. The tritium was released at Segment 72 .

\section{RESULTS}

Figures 4 to 7 show that the simulated tritium concentration profiles are in good agreement with the measurements. The model overestimates the peak concentrations by 3 to $15 \%$, as shown in Table 2. Table 2 also shows that the model underestimates the transport times of the concentration peak by 18 to $37 \%$. The discrepancies in the travel time could result from uncertainties in the start the release.

\section{CONCLUSIONS}

The revised STREAM code, an aquatic emergency response computer program, was set up to model the transport of pollutants from a release point in K-Area to Savannah, Georgia through Indian Grave Branch, Pen Branch, the SRS swamp, Steel Creek, and the Savannah River. To evaluate the accuracy of this model, it was used to simulate a 1991 accidental release of tritiated water from K-Reactor. The model overestimates the peak concentrations by 3 to $15 \%$ and underestimates the transport times of the concentration peak by 18 to $37 \%$. The discrepancies in the travel time could result from uncertainties in the start the release. The revised STREAM code did a good job of simulating both the timing and the magnitude of the maximum observed tritium concentration. This gives confidence that the code can perform well both for emergency response and other engineering or safety analyses. 


\section{REFERENCES}

1. Kuo-Fu Chen, "Revised STREAM Code and WASP5 Benchmark," WSRCRP-95-598, May 1995.

2. R. B. Ambrose, T. A. Wool, and J. L. Martin, "The Water Quality Analysis Simulation Program, WASP5, Part A: Model Documentation; Part B: Input Dataset," Environmental Research Laboratory, Office of Research and Development, U.S. Environmental Protection Agency, Athens, Georgia, September 20, 1993.

3. D. M. Hamby, R. P. Addis, D. M. Beals, J. R. Cadieux, W. H. Carlton, D. L. Dunn, G. Hall, D. W. Hayes, R. Lorenz, M. V. Kantelo and R. W. Taylor, "Emergency Response Monitoring Activities and Environmental Impact of K-Reactor Aqueous Tritium Release of December 1991 (U)," WSRC-RP-92186, February 7, 1992.

4. C. S. Bennett, T. W. Cooney, K. H. Jones, and J. W. Gissendanner, "Water Resources Data South Carolina Water Year 1992," U.S. Geological Survey Water-Data Report SC-92-1. 


\section{APPENDIX A}

The Manning Equation was used to estimate the channel flow areas. The Manning Equation is expressed as:

$$
Q=\frac{1.49}{n} A R^{\frac{2}{3}} S^{\frac{1}{2}}
$$

where $Q=$ volumetric flow rate, $\mathrm{ft}^{3} / \mathrm{s}$

$\mathrm{n}=$ Manning roughness coefficient

$\mathrm{A}=$ flow area, $\mathrm{ft}^{2}$

$\mathrm{R}=\mathrm{P} / \mathrm{A}=$ hydraulic radius, $\mathrm{ft}$

$\mathrm{P}=$ wetted perimeter, $\mathrm{ft}$

$\mathrm{S}=$ channel slope

The flow area was assumed to be trapezoidal, as shown following:

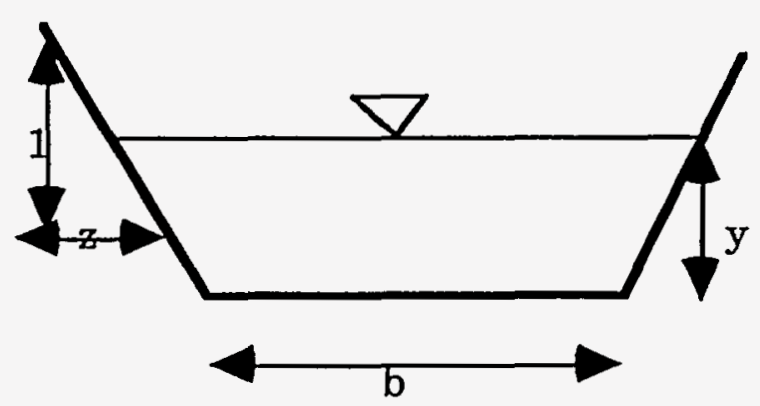

The cross section area is: $A=y(b+z y)$

The wetted perimeter is: $p=b+2 y \sqrt{1+z^{2}}$

The hydraulic radius is: $R=\frac{(b+z y) y}{b+2 y \sqrt{1+z^{2}}}$

The values used to estimate the flow area are:

\begin{tabular}{|c|c|c|c|c|c|}
\hline & b & $\mathbf{z}$ & $\mathrm{n}$ & $\mathrm{S}$ & $\stackrel{\mathrm{Q}}{\mathrm{a}}$ \\
\hline en & 6 & 5 & 0.04 & 0.003 & 450 \\
\hline wa & 2000 & 1 & 0.12 & 0.00027 & 450 \\
\hline River & 70 & 1.75 & 0.035 & 0.000124 & 10,000 \\
\hline
\end{tabular}

With given values of the parameters $(b, z, n, S$ and $Q), y$ can be solved from Equations 1 to 4 . The cross section area, $\mathrm{A}$, is obtained from Equation 2 after $\mathrm{y}$ is known. 
Table 1

Input Flow

\begin{tabular}{|c|c|c|c|}
\hline Location & Pen Branch (Rd A13.2) & Steel Creek (Rd A) & $\begin{array}{c}\text { Savannah River (Augusta) } \\
02197000\end{array}$ \\
\hline Stage ID & & 021973565 & 02197000 \\
\hline $\begin{array}{l}\text { Day } \\
12 / 22 / 91\end{array}$ & $\begin{array}{c}\text { cfs } \\
459\end{array}$ & cfs & cfs \\
\hline $12 / 22 / 91$ & 459 & 83 & 5850 \\
\hline $12 / 23 / 91$ & 461 & 84 & 5940 \\
\hline $12 / 24 / 91$ & 475 & 89 & 6450 \\
\hline $12 / 25 / 91$ & 240 & 84 & 6710 \\
\hline $12 / 26 / 91$ & 80 & 79 & 6680 \\
\hline $12 / 27 / 91$ & 66 & 79 & 7240 \\
\hline $12 / 28 / 91$ & 90 & 113 & 7050 \\
\hline 12/29/91 & 115 & 146 & 7400 \\
\hline $12 / 30 / 91$ & 75 & 100 & 8010 \\
\hline $12 / 31 / 91$ & 69 & 94 & 8070 \\
\hline $1 / 1 / 92$ & 67 & 92 & 8010 \\
\hline $1 / 2 / 92$ & 66 & 90 & 7470 \\
\hline $1 / 3 / 92$ & 72 & 92 & 8100 \\
\hline $1 / 4 / 92$ & 71 & 90 & 6450 \\
\hline $1 / 5 / 92$ & 68 & 87 & 7390 \\
\hline $1 / 6 / 92$ & 65 & 84 & 7220 \\
\hline $1 / 7 / 92$ & 65 & 83 & 9590 \\
\hline $1 / 8 / 92$ & 66 & 82 & 8950 \\
\hline $1 / 9 / 92$ & 66 & 82 & 7140 \\
\hline $1 / 10 / 92$ & 67 & 82 & 7090 \\
\hline $1 / 11 / 92$ & 67 & 81 & 8500 \\
\hline $1 / 12 / 92$ & 68 & 80 & 6300 \\
\hline $1 / 13 / 92$ & 109 & 122 & 6980 \\
\hline $1 / 14 / 92$ & 122 & 120 & 9460 \\
\hline $1 / 15 / 92$ & 83 & 85 & 9290 \\
\hline $1 / 16 / 92$ & 75 & 77 & 7900 \\
\hline $1 / 17 / 92$ & 73 & 72 & 7750 \\
\hline $1 / 18 / 92$ & 72 & 69 & 6420 \\
\hline 1/19/92 & 105 & 95 & 7520 \\
\hline $1 / 20 / 92$ & 89 & 76 & 7680 \\
\hline $1 / 21 / 92$ & 81 & 81 & 9350 \\
\hline & 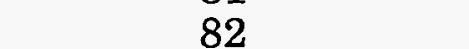 & 100 & \\
\hline
\end{tabular}


Table 2.

Model Comparison Summary

Sample Location Peak Concentration Travel Time Meas. Model \% Error Hour Hour

Steel Creek Highway 301 Becks Ferry Abercorn Creek $\begin{array}{lll}137.0 & 86.4 & -37\end{array}$

$134.5 \quad 100.8 \quad-25$

$185.0 \quad 151.2 \quad-18$ $\begin{array}{lll}197.5 & 158.4 & -20\end{array}$
Peak Concentration Meas. Model \% Error $\mathrm{pCi} / \mathrm{ml} \mathrm{pCi} / \mathrm{ml}$ $1364.51400 .0 \quad 3$ $\begin{array}{lll}66.9 & 69.1 & 3\end{array}$ $\begin{array}{lll}56.2 & 61.4 & 9\end{array}$

$\begin{array}{lll}52.7 & 60.6 & 15\end{array}$ 
Figure 1. Path followed by tritium from $\mathrm{K}$ Area to the Savannah River estuary after December 1991 release

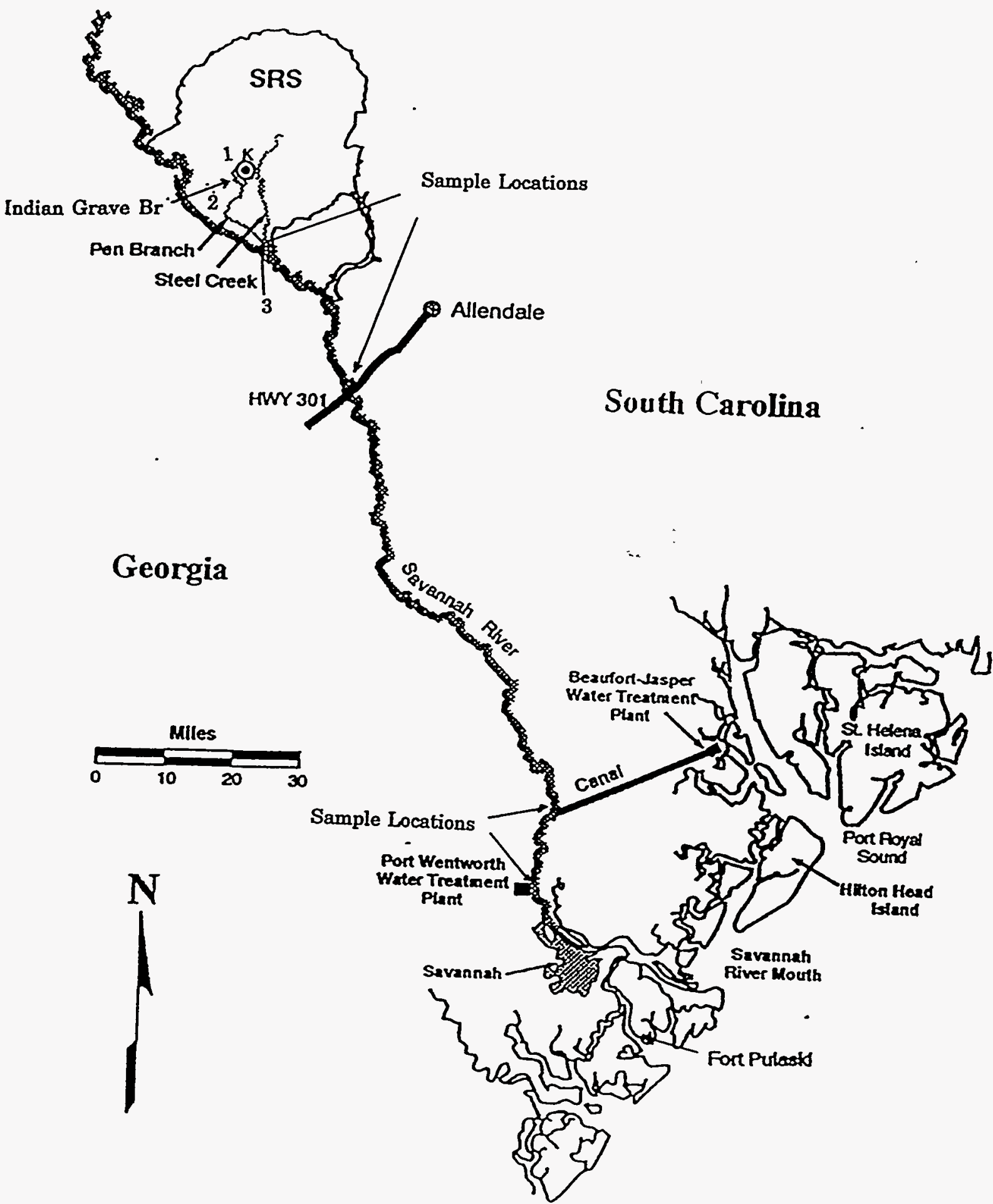


Figure 2. Model Schematics (Not to Scale)

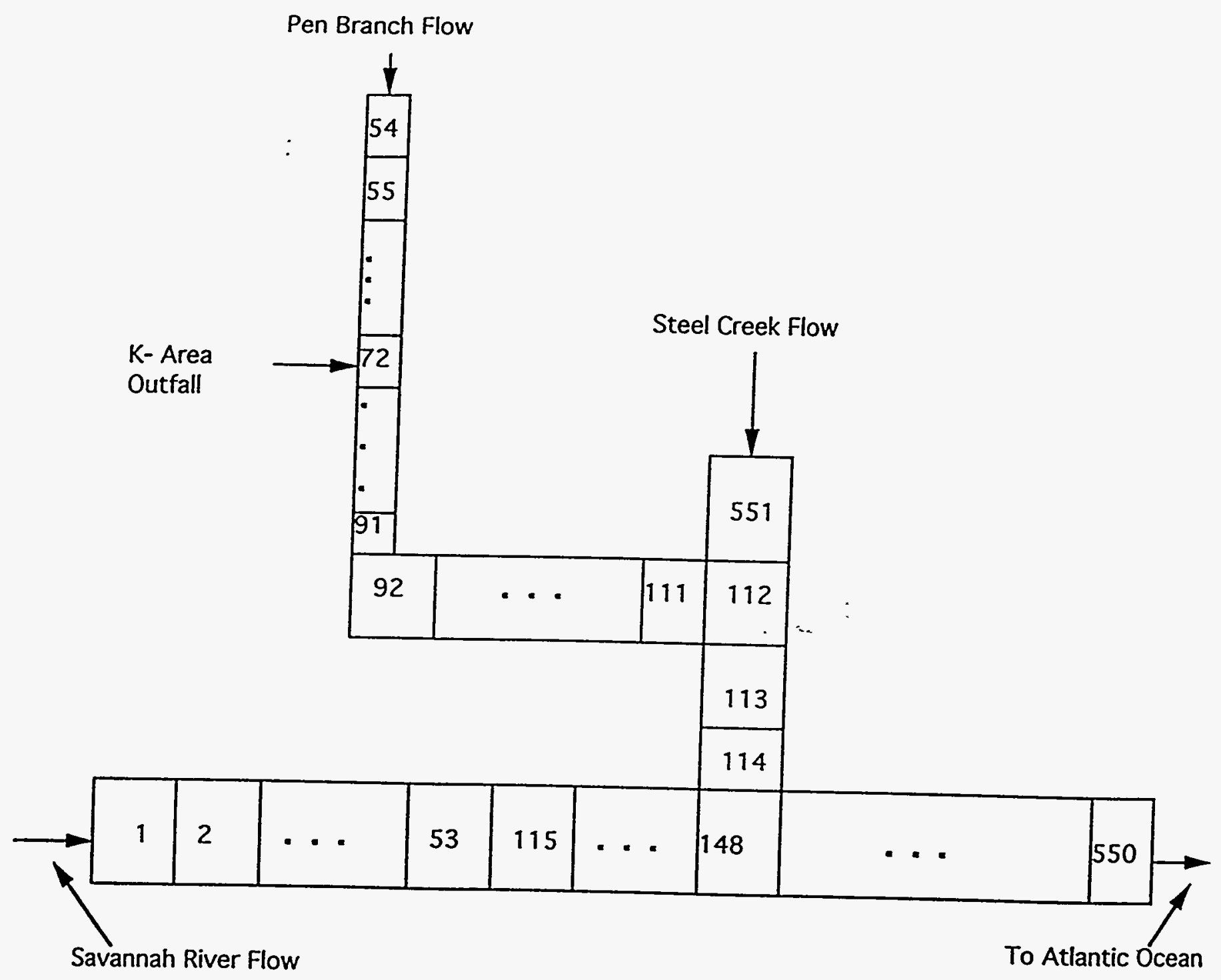


Figure 3. Measured Savannah River Stage at Steel Creek Mouth

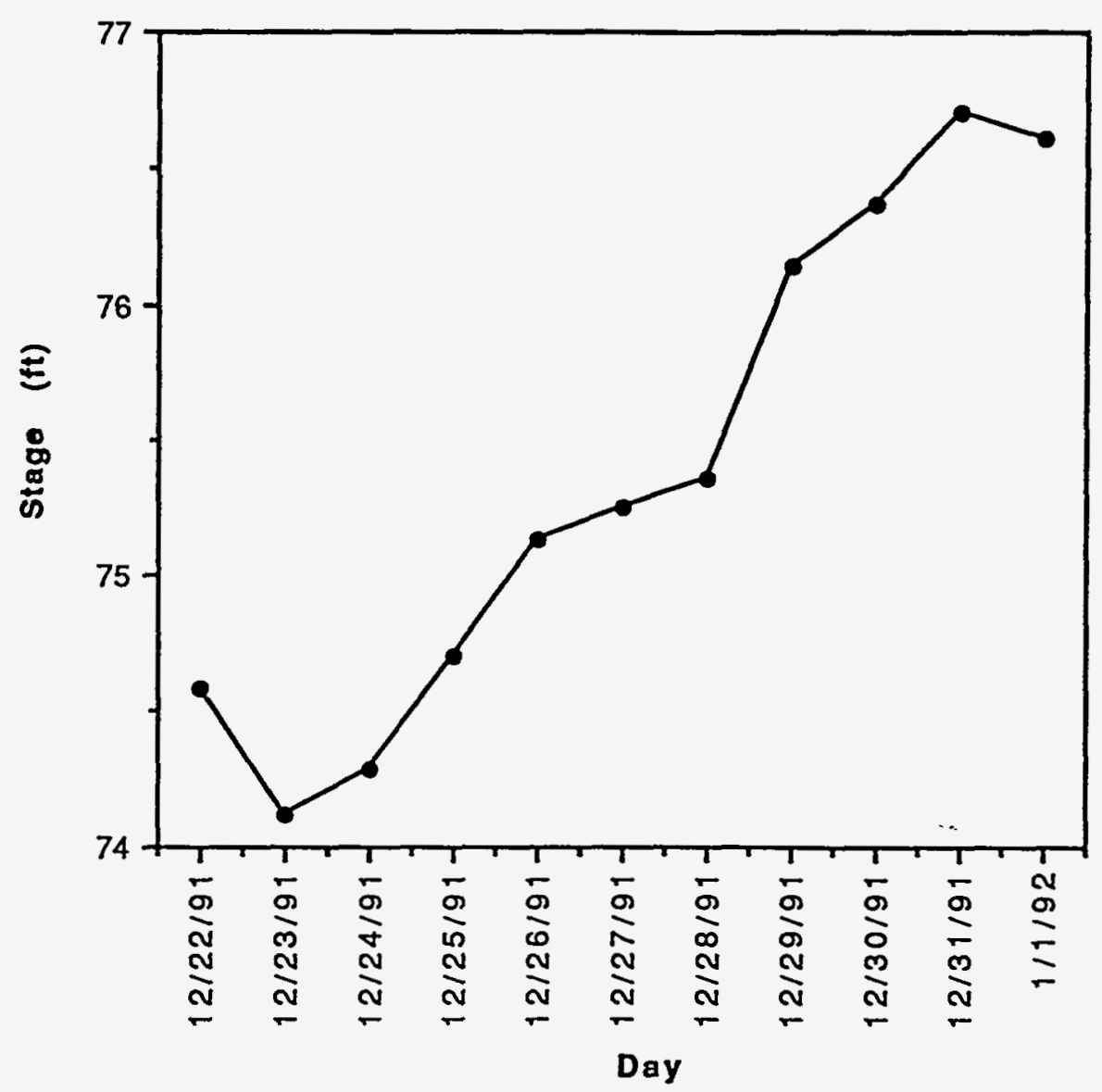


Figure 4. Model Simulation for 1991 K-Reactor Tritiated Water Release Incident (Tritium Concentration at Steel Creek)

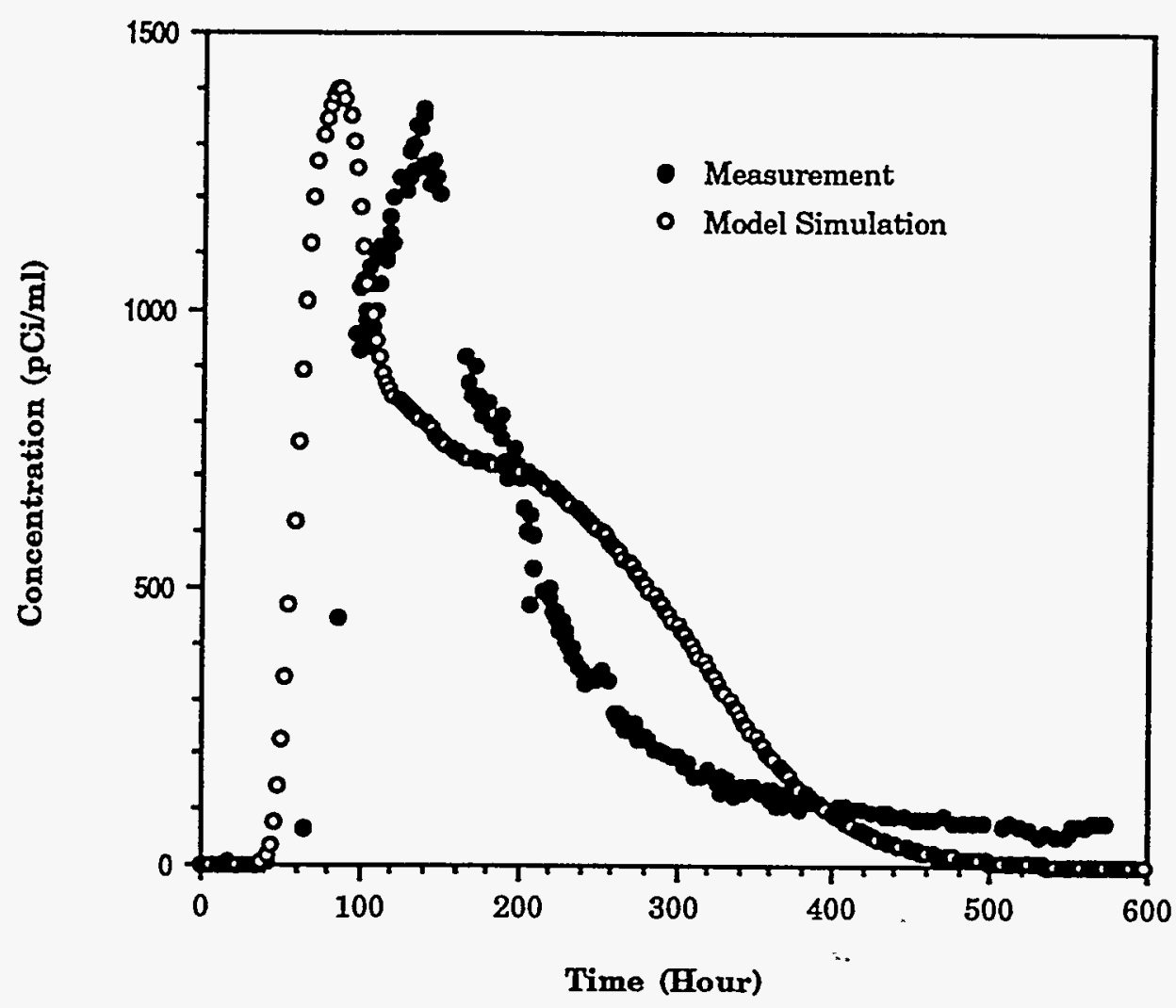


Figure 5. Model Simulation for $1991 \mathrm{~K}$-Reactor Tritiated Water Release Incident (Tritium Concentration at Highway 301)

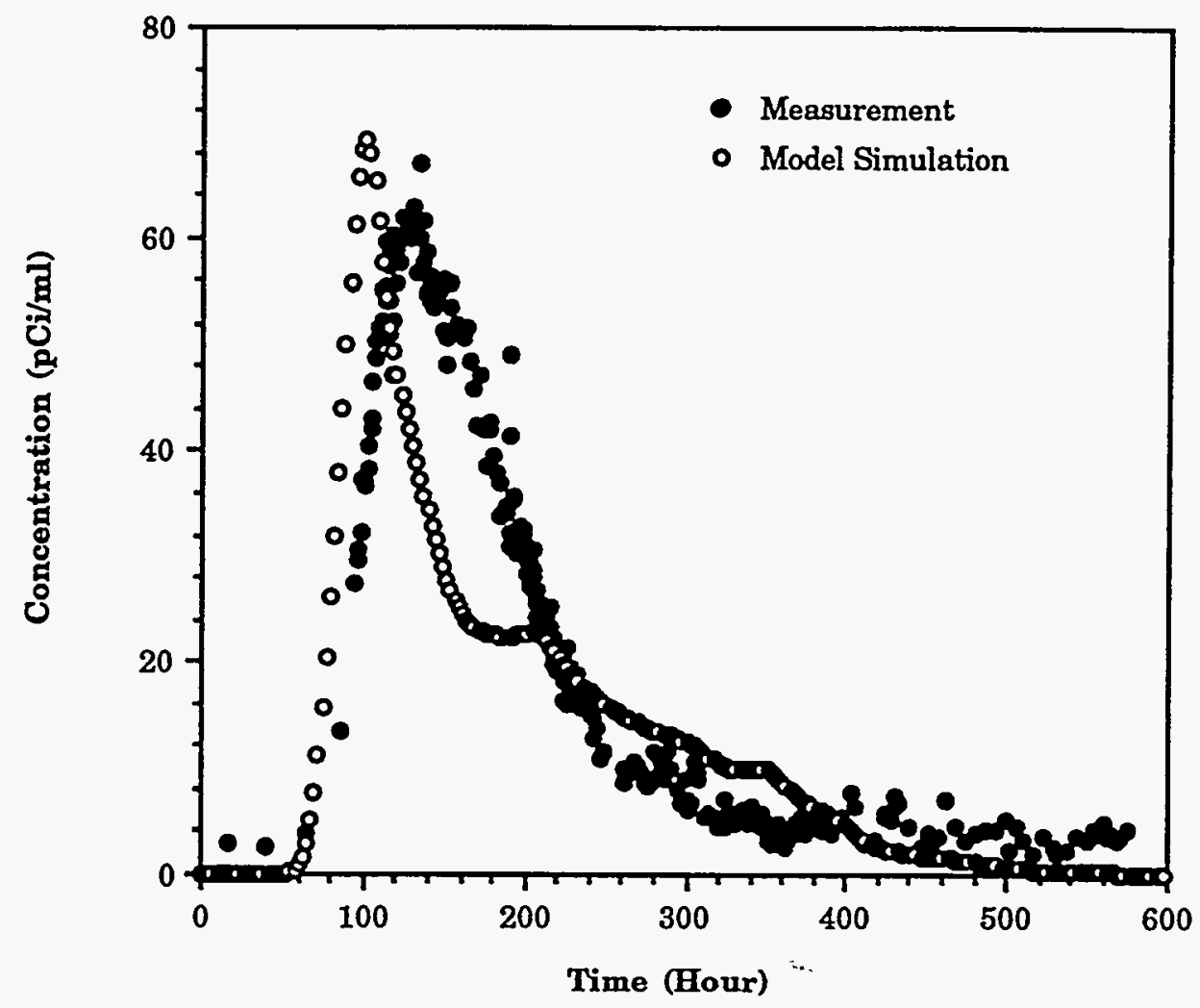


Figure 6. Model Simulation for 1991 K-Reactor Tritiated Water Release Incident (Tritium Concentration at Becks Ferry)

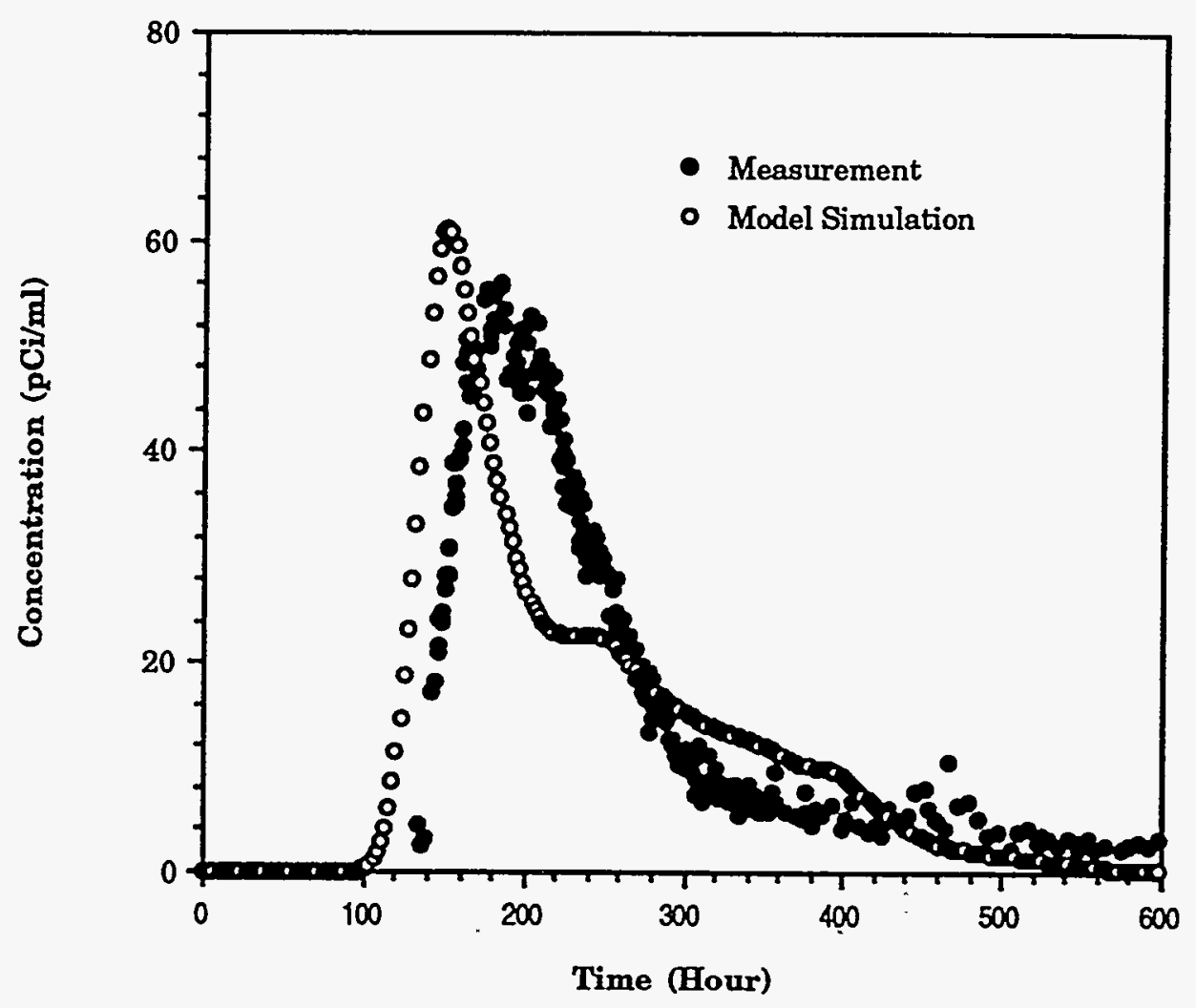


Figure 7. Model Simulation for $1991 \mathrm{~K}$-Reactor Tritiated Water Release Incident (Tritium Concentration at Abercorn Creek)

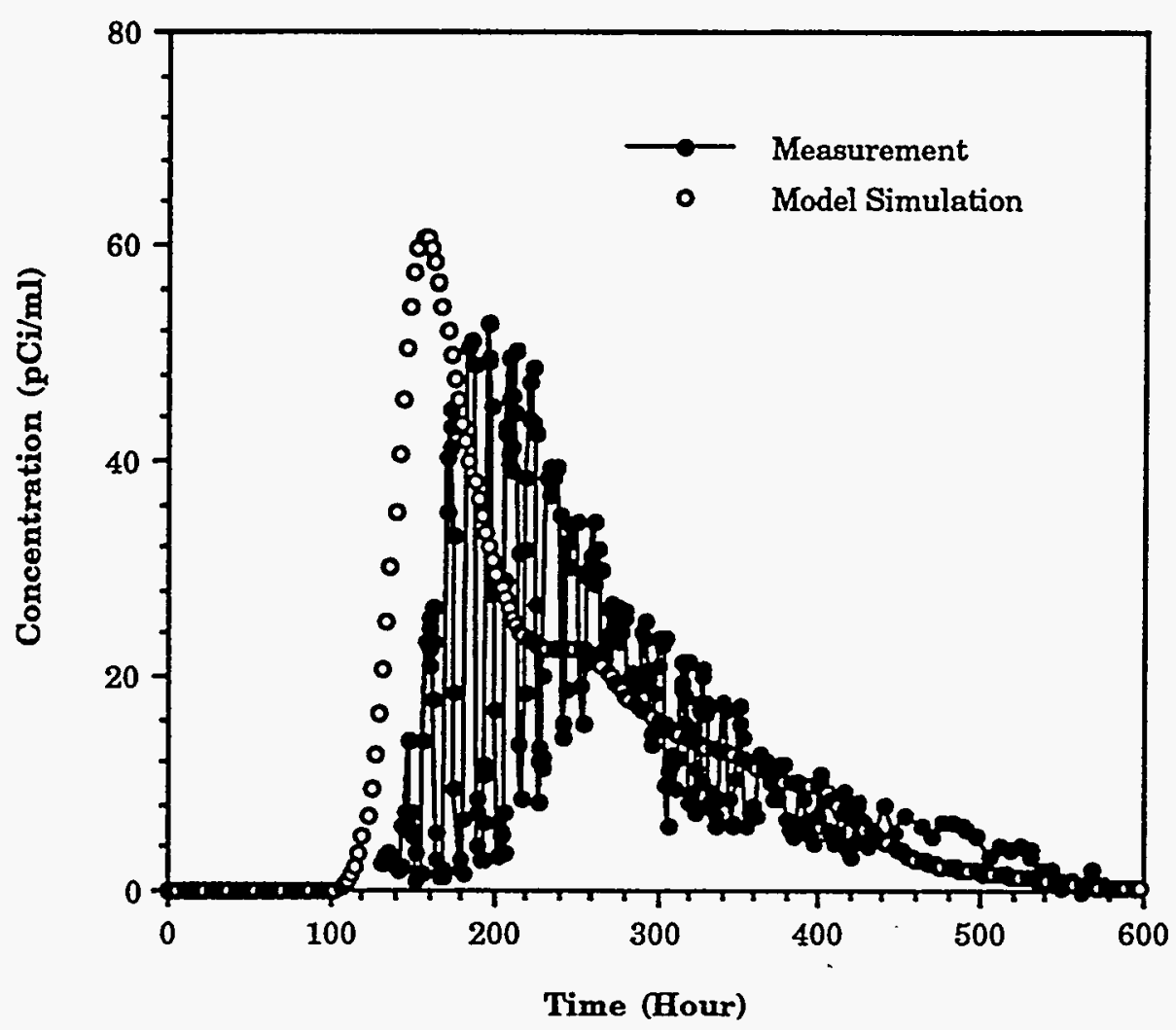


REVISED STREAM CODE BENCHMARKING WITH $1991 \mathrm{~K}$ REACTOR TRITIATED AQUEOUS RELEASE INCIDENT (U)

\section{DISTRIBUTION}

R. P. Addis, 773-A

A. L. Boni, 773-A

W. A. Emel, 735-A

B. L. O'Steen, 773-A

A. J. Garrett, 773-A

D. W. Hayes, $735-A$

D. P. Griggs, 773-A

C. H. Hunter, 773-A

Kuo-Fu Chen, 773-A

SRTC Records(4), 773-52A

ETG Records(5), 773-A 